\title{
EIKIT PAŽIÜRĖT, KAIP NETURI BŪT: PSICHIKOS SVEIKATOS POLITIKOS RAIDA IR JOS REZULTATAI
}

\author{
EGLE ŠUMSKIENĖ, DAINIUS PÜRAS \\ VILNIAUS UNIVERSITETAS
}

Straipsnyje pristatomas kokybinis ekspertu tyrimas, atliktas 2012-2013 metais igyvendinant projekta "Išš Tyrimo metu iš psichikos sveikatos politikos "senbuviu“ ir jos kritiku perspektyvos siekiama ivertinti psichikos sveikatos priežiūros sistemos raida Nepriklausomybès laikotarpiu, ypatinga dèmesị skiriant santykiui tarp sovietmečio praktiku ir bandomu diegti moderniu inovaciju. Straipsnio autoriai daro išvadas, kad nevyriausybiniu organizaciju iniciatyva diegiamos paslaugos savo pažangumu išsišoka iš bendro stagnatyvaus konteksto ir kelia grésme psichikos sveikatos priežiüros sistemos homeostazei. Inertiškumu pasižyminti psichikos sveikatos priežiūros sistema i šiuos iššūkius reaguoja dviem būdais: arba šios paslaugos "numarinamos“ kaip nepasiteisinusios ir grižtama prie tradiciniu paslaugu teikimo büdu, arba integruojamos i iprastas sistemines praktikas ir tik sustiprina iki tol egzistavusia institucine sąranga. Tyrima finansavo Lietuvos mokslo taryba (sutarties Nr. SIN-16/2012).

\section{IVADAS}

2012-2013 metais grupè mokslininkų vykdė projektą „Iššūkiai igyvendinant Lietuvos psichikos sveikatos politiką". Vykdant projektą buvo analizuojama Lietuvos psichikos sveikatos politikos raida nepriklausomybés metais, jos trajektoriją lemiantys veiksniai, pagrindiniai pasiekimai, vertintas jos veiksmingumas sprendžiant aktualias visuomenės sveikatos problemas (Pūras, Šumskienè, Veniūtè, Murauskienè, Šumskas, Diržienè, Juodkaitè, Šliužaitè, 2013). 
Analizè atskleidè, jog, nepaisant tinkamai suformuluotos teisinès bazès, egzistuoja sisteminès psichikos sveikatos politikos svarbiausių principu ir prioritetu igyvendinimo spragos. Nefunkcionuoja nepriklausomos stebėsenos mechanizmai, kurie paprastai laikomi reikšminga psichikos sveikatos sistemos tobulinimo grandimi, orientuota ị žmogaus teisių sistemoje užtikrinima, investuojamų finansinių ir žmogiškujjų išteklių panaudojimo efektyvumą ir veiklos rezultatų vertinimą. Apsiribojant vidiniais ir sistemai lojaliais jos funkcionavimo vertinimo mechanizmais, politiškai proteguojama ir finansiškai remiama tradicinè paslaugu infrastruktūra, neskatinama modernių prevencinių ir bendruomeninių paslaugu plètra. Egzistuoja nepalankus visuomenès nuostatų, valdžios institucijų sprendimų ir psichikos sveikatos priežiūros sistemos veikimo bei vertinimo būdų derinys, kurio atskiri fragmentai sustiprina vienas kitą ir sunku išskirti šio sudètingo konstrukto sudedamujų dalių priežastingumo ryšius .

Pūro ir kt. (2013) atlikto tyrimo rezultatai parodè, kad Lietuvos psichikos sveikatos priežiūros sisteminès spragos yra žymiai stipriau nulemtos svarbių veikejjų grupių vyraujančių požiūrių, o finansinių išteklių trūkumas nèra pakankamas argumentas. Pirmąji nepriklausomybès dešimtmeti disponuojant mažesnèmis finansinėmis galimybėmis buvo dedama daugiau pastangu igyvendinti šiuolaikinius principus ir investuoti i veiksmingas inovacijas negu 2001-2013 metais, kai buvo grižta prie sovietmečiu îprastų praktikų.

Šie apibendrinimai didžiąja dalimi buvo grindžiami projekto vykdymo metu atliktu kokybiniu ekspertų tyrimu, kurio metu surinkti duomenys ne tik tapo pagrindu išskirti esminius tolesnès vykdytos analizės kintamuosius, bet ir leido identifikuoti pagrindines sistemines problemas, ju priežastis ir ịvertinti vidines bei išorines aplinkybes, lèmusias Lietuvos psichikos sveikatos priežiūros sistemos raidą. Atskiro aptarimo nusipelno atliekant kokybini ekspertų tyrimą išryškèjęs naujas institucinis atsakas i psichikos sveikatos srityje diegiamas naujoves, kuris pasireiškia diegiamų inovacijų asimiliavimu, jų integravimu i̇ iprastas sistemines praktikas. Šiame straipsnyje pristatomi kokybinio ekspertų tyrimo rezultatai.

Tyrimo tikslas: jungiant psichikos sveikatos politikos „senbuvių“ ir jos kritikų perspektyvas ivvertinti psichikos sveikatos priežiūros sistemos 
raidą nepriklausomybės laikotarpiu, ypatingą dėmesi skiriant santykiui tarp sovietmečio praktikų ir bandomų diegti modernių inovacijų.

Tyrimo uždaviniai:

- Ivertinti psichikos sveikatos priežiūros politikos formavimo praktikas itraukiant skirtingų sričių ekspertus.

- Aptarti visuomenės psichikos sveikatos būklę ir ją veikiančius veiksnius.

- Identifikuoti psichikos sveikatos priežiūros sistemos problemas, ju priežastis ir pasireiškimo būdus.

- Išanalizuoti ryškiausius bandymus kurti naujas psichikos sveikatos priežiūros paslaugas ir jų integravimo iz paveldètas institucines praktikas ypatumus.

\section{TYRIMO METODOLOGIJA}

Tyrimu buvo siekiama surinkti giluminę informaciją apie Lietuvos psichikos sveikatos sistemos kaita, aprèpti visą nagrinejjamo fenomeno kompleksiškumą tiek chronologiškai atskleidžiant psichikos sveikatos sistemos raidą atkūrus Lietuvos nepriklausomybę, tiek analizuojant institucijų sisteminius ryšius, ịstaigų veiklą bei priimamus politinius sprendimus. Tyrimas buvo vykdomas pasitelkus kokybini ekspertų interviu metodą kaip duomenis generuojantį instrumenta, kuriuo siekiama rekonstruoti ekspertinį žinojimą (Pfandenhauer 2009, 84). Asmenybių lygmeniu psichikos sveikatos sistemos kaitai ittaką dare îvairių sričiu atstovai - politikai, vyriausybės nariai, mokslininkai, psichikos sveikatos priežiūros i̇staigų vadovai, nevyriausybinių organizacijų veikèjai, psichosocialinę negalią turintys asmenys. Iš jų buvo atrinkti devyni ekspertai, kurie dalyvavo kokybiniame ekspertų tyrime.

Buvimas ekspertu yra santykinis statusas (Meuser, Nagel 2005), kuris yra igyjamas tyrejui tam tikrą asmenų ratą pripažistant kaip turintį specifiniư, tyrimo sričiai reikšmingų žinių (Liebold, Trienczek, 2002). Meuserio ir Nagelio (2009) teigimu, ekspertas yra vykdytojas ir vystytojas, arba atsakingas už atitinkamus tam tikros srities pokyčius. Pfadenhaueris (2009) papildo šiuos vokiečių autorius reikšmingomis ekspertų žiniomis apie problemų priežastis ir ju sprendimų principus. Bogneris ir Menzas (2001) pabréžia ekspertų veiklos daromą îtaką atitinkamai teminei sričiai. Jų teigimu, eksperto žinios, veiklos orientacija, prioritetai sudaro 
galimybę igyvendinti savo įsitikinimus tam tikrame organizaciniame kontekste ir tai savo ruožtu daro didelę ịtaką kitų šios srities dalyvių veiklos sąlygoms.

Tyrimo ekspertai buvo atrinkti remiantis trimis pagrindiniais kriterijais: a) daugiau nei dešimties metų darbas formuojant, igyvendinant psichikos sveikatos politika, vertinant arba inicijuojant jos reforma; b) daugialype patirtis psichikos sveikatos srityje ir nacionalinis arba tarptautinis ekspertizès pripažinimas; c) ekspertų ìvairovè atstovavimo valdžios lygmenims, nevyriausybinèm organizacijom, akademiniam sektoriui, paslaugu vartotojam ir pan. požiūriu.

Iš ekspertų pasirinkimo matyti, jog tarpusavyje jie gerokai skiriasi: užimamomis pareigomis (valdinininkai - politikai - visuomenès veikèjai - mokslininkai - medikai); sektoriumi (viešasis - nevyriausybinis); vieni ju aktyviai prisidejo prie globos paslaugu sistemos kūrimo, kiti daugiau užėmè kritiko, oponento poziciją.

Pusiau struktūruoti naratyviniai interviu su devyniais tyrimo ekspertais vyko 2012 m. spalio-2013 m. vasario mèn., pokalbio trukmè - nuo 1 iki 1,5 val. Interviu sudarė aštuoni klausimai, kuriais buvo siekiama išsiaiškinti Lietuvos psichikos sveikatos sistemos kaita, šios kaitos veiksnius, svarbiausius etapus, pagrindinius pasiekimus ir klaidas bei reformos poveiki Lietuvos visuomenès psichikos sveikatai. ${ }^{1}$

\section{TYRIMO DUOMENYS}

\section{ELITIZMAS FORMUOJANT PSICHIKOS SVEIKATOS POLITIKA}

Ekspertų atsakymai i i̇vadini tyrimo klausimą apie jų ísitraukimą i psichikos sveikatos politikos formavimą išryškino reikšmingą tendenciją kuri pasitvirtino ir tolesneje tyrimo eigoje kaip pagrindinis tyrimo duomenų analizès leitmotyvas - galios santykiai negalią turinčių asmenų atžvilgiu ir nepakankamai išnaudojamas profesionalų bei mokslininkų potencialas.

\footnotetext{
${ }^{1}$ Interviu buvo analizuojami remiantis Meuserio ir Nagelio (2005) siūlomais šešiais vertinimo žingsniais: (1) transkripcija; (2) parafrazavimu; (3) kodavimu; (4) teminiu palygini$\mathrm{mu}$ (kategorizavimu); (5) sociologiniu konceptualizavimu (empiriniu generalizavimu); (6) teoriniu generalizavimu.
} 
Tyrimo duomenys leido išskirti tris ekspertų dalyvavimo psichikos sveikatos politikoje būdus. Vykdomosios ir įstatymų leidžiamosios valdžios atstovai minejo aktyvų, nuolatini dalyvavima, i̇sitraukimą i strateginiu sprendimu priemimą: per mano rankas praejo visi teisés aktai, kurie reglamentuoja šita sritị. Fragmentiškas buvo mokslo srities ekspertu ir psichiatru įsitraukimas i politikos sriti dalyvaujant darbo grupèse, kurios skirtos parengti konkretų teisės aktą (tyrimo dalyviai konkrečiai minejjo Psichikos sveikatos priežiūros isstatymą ir Psichikos sveikatos strategiją). Galiausiai - minimalus arba nulinis pačios tikslinės grupès atstovų dalyvavimas, kuris išryškejjo pokalbio su psichosocialinę negalią turinčia eksperte: Aš turbūt net ir nebuvau pakviesta kažkur kalbèti, pasakyti kažkokiu pasiūlymu, nei prie apvalaus stalo. Svarbu paminèti, kad ši tyrimo dalyvė yra ekspertė ne tik dèl savo asmeninès negalios patirties (angl. lay expert), bet ir dèl aktyvaus dalyvavimo nevyriausybinių organizaciju veikloje, tarptautiniuose projektuose, mokymuose kaip lektorè. Ji išryškino bendrą tendencija jog psichosocialinę negalią turintys asmenys neįtraukiami i sprendimų prièmimą politiniu lygmeniu ir teigè prisimenanti tik vieną savo kolega, kuris, kol buvo gyvas, viešojoje erdvejje reiškèsi ir buvo pripažintas kaip šios socialinès grupės interesų atstovas. Ši pašnekove išryškino abipusi vengimą bendradarbiauti: jos teigimu, politinę atskirti ne mažiau lemia ir psichosocialinę negalią turinčių asmenų pasyvumas, jų noras išlikti anonimais.

Beveik visi tyrimo dalyviai išskyrè Psichikos sveikatos strategiją kaip reikšmingiausią šios srities dokumentą ir dauguma akcentavo savo vaidmeni prisidedant prie jo kūrimo, kaip aukščiausią politinio įsitraukimo ir priklausomybės psichikos sveikatos sistemos reformatorių elitui išraišką. Dalis respondentų minėjo buvę šio teisès akto iniciatoriais, kiti dalyvavo jos rengimo darbo grupeje, treti užsièmè susijusios teisinès bazès derinimu. Nenuostabu, kad šis teisès aktas ${ }^{1}$, gimęs kaip i̇vairių sričiu ekspertų bendradarbiavimo produktas, tarptautiniu mastu yra pripažįstamas kaip kokybiškas ir jo sukūrimo laikotarpiu pelnęs Lietuvai regiono lyderès titulą.

\footnotetext{
${ }^{1}$ Plačiau apie ši teisès aktą ir jo igyvendinimą reformuojant Lietuvos psichikos sveikatos sistemą bus tolesniuose skyriuose.
} 


\section{PRASTA VISUOMENĖS PSICHIKOS SVEIKATA - SOVIETMEČIO PAVELDO IR NEIVYKSTANČIOS REFORMOS İKAITE்}

Delsimas vykdyti psichikos sveikatos sistemos reformą anaiptol nereiškia, jog esama institucinè sąranga demonstruoja gerus rodiklius ir teigiamai atsiliepia i visuomenės psichikos sveikatos poreikius. Nebuvo nẻ vieno eksperto, palankiai atsiliepusio apie Lietuvos visuomenès psichikos sveikatos būklę ir optimistiškai vertinusio jos perspektyvas, bent jau artimiausiu laikotarpiu. Ekspertai išskyrẻ šiuos visuomenės psichikos sveikatą Lietuvoje veikiančius veiksnius: asmens ir piliečio teisiu ignoravimas, ekonominės politinės farmacijos pasikeitimas, ekonominio saugumo praradimas, pokario ir okupacijos psichologinis paveldas, pesimizmas, pasyvumas kaip nacionaliniai bruožai, socialinė atskirtis, sovietmečio suformuotas nepasitikèjimas valdžios institucijomis, stresas, valdžios struktūrų ịtaka, vertybinių orientacijų kaita, neigiama žiniasklaidos įtaka ir žinių apie psichikos sveikatą trūkumas.

Opiausios visuomenès psichikos sveikatos problemos identifikuojamos kaip latentinio, lètinio pobūdžio ir apimančios ištisus regionus ar socialines grupes. Kai kurios iš šių problemų (alkoholizmas, netolerancija skirtybėms) ekspertų pripažistamos kaip sovietmečio paveldas, kitos tokios kaip nesaugumo jausmas, agresyvumas, suicidinis elgesys, stresas, pesimizmas - siejamos su lūžio laikotarpiu, perẻjimu prie rinkos ekonomikos, socialinio saugumo praradimu.

Ekspertai daug dėmesio skyrè istoriniams aspektams, pradedant nuo sovietmečio ịtakos, baigiant pastangomis kurti demokratinę valstybę. Visi sutarè, kad socialistinès santvarkos poveikis, net ir praejus beveik ketvirčiui amžiaus, vis dar juntamas. Sovietmečio neigiamą įtaką praradimus ir tautos patirtą kolektyvinę traumą itin pabrèžè visi tyrime dalyvavę akademinio sluoksnio atstovai, išskirdami populiacijos skaičiaus mažejimą ir praradimus dèl emigracijos, karo, trèmimų; nuo sovietmečio mažai pakitusị sistemini ir institucini paveldą; sužalotą visuomenės sąmonę ir išlikusius baimès, ịtarumo jausmus, kurie anuomet padèjo išgyventi, o dabar trukdo formuotis gyvybingoms pilietinėms demokratinėms visuomenèms. Atkūrus nepriklausomybę toliau vykę pokyčiai nesukūrẻ saugumo jausmo, stichiškas laisvos rinkos kūrimasis taip pat turèjo neigiamą poveiki visuomenès ir atskiru jos nariu psichikos sveikatai. Psichikos sveikatos sistemos reforma nei pirmaisiais nepriklausomybès 
metais, nei vẻliau neatsidūrè politinès darbotvarkès viršūnėje, nebuvo dedamos pastangos modernizuoti, "desovietizuoti“ ir pritaikyti ją prie sparčiai kintančiu visuomenės poreikių. Nebuvo dedamos politinės pastangos sukurti institucinius saugiklius, kurie amortizuotų santvarkos pokyčių nulemtus sunkumus, todèl nerimą dèl socialinių, ekonominių, politinių pokyčių išgyvenantys žmonès rado destruktyvių nusiraminimo būdų, pasireiškusių priklausomybėmis, ị kitus ir save nukreiptomis agresijos formomis. Valstybės paliktas spragas tradicinėse demokratinėse valstybėse paprastai užpildo nevyriausybinis sektorius, tačiau, būdamas silpnas, Lietuvoje šis sektorius nesprendè visuomenės psichikos sveikatos problemų ir neužtikrino saugumo poreikio: tyrime dalyvavęs akademinio sluoksnio atstovas ir praktikuojantis psichiatras atkreipè dèmesị, jog nepriklausomybès laikotarpiu nebuvo išugdytas gebejjimas prisiimti atsakomybę tiek už savo gyvenimą, tiek už visą visuomenę.

Apie sistemos nesèkmes sprendžiant aukščiau i̇vardytas problemas signalizuoja ne tik faktas, kad jos nedingsta ir toliau aštrëja, bet ir nauju arba išvestinių jų formų radimasis - pvz., ekspertai mini jaunimo savižudybes, tarp paauglių plintančią narkomaniją psichikos sveikatos problemas darbovietėse, įskaitant mobingą (žeminimą ir patyčias darbo vietoje).

Ivardydami daugumą problemų ekspertai dažniausiai operavo ịprastiniais, žiniasklaidos suformuluotais įsitikinimais ir vaizdiniais, buitine kalba ir tradiciniais pavyzdžiais. Pavyzdžiui, apie jaunimo patiriamą bendraamžių spaudimą rūkyti. Jeigu tu nesi rūkęs ne karto, tai tu esi žalia kažkokia tai morka; visuomeniniame diskurse dažnai pabrèžiamą alkoholio vartojimo paplitimą kaime: turbūt jau negeriančiu, blaiviu rajonu, kaimu visai nebelikę. Visi geria, tempia tuos bambalius, geria; vaikišką smalsuma, kuris gali lemti ankstyvą eksperimentavimą su psichiką veikiančiomis medžiagomis: septyneriu, net šešeriu metu vaikai pirma karta pabando psichoaktyvias medžiagas - tai tabaka, alkoholi. Reikšmingesnès ekspertų ižvalgos apie naujas problemas, sinergetini ir daugialypi jų efektą, netradiciniai paaiškinimai, kvestionuojantys îprastus priežastingumo modelius. Pavyzdžiui, akademinio sluoksnio atstovas akcentavo, kad augantis paauglių savižudybių skaičius yra susijęs su priklausomybių problematikos didejjimu. Eksperto nuomone, ši problema nèra pripažinta ir sprendžiama, jis pasigenda psichikos sveikatos politikos lygmens 
pastangu identifikuoti tikslines grupes ir vykdyti pirmojo psichozès epizodo prevenciją. Kitas ekspertas, remdamasis atliktais tyrimais, ieško sąsajų tarp nekompetentingos bei korumpuotos policijos veiklos ir stebėtinai aukšto vyrų suicidų skaičiaus. Jo teigimu, tikètina, kad dalis neištirtų vyrų žmogžudysčių yra tiesiog nurašomos kaip savižudybės, todèl kvestionuotinas aukštas savižudybių skaičius.

\section{LIETUVOS PSICHIKOS SVEIKATOS SISTEMOS PROBLEMOS}

Tradicinis nesėkmių tam tikroje viešosios politikos srityje pateisinimas yra finansavimo stygius. Pinigus psichikos sveikatos sistemoje minejo ne vienas tyrimo ekspertas. Dalis respondentų daugiau pabrèžè išorines sąlygas, tokias kaip žemą ekonomikos išsivystymą kuris lèmė Lietuvos atsilikimą nuo turtingesnių valstybių vystant psichikos sveikatos priežiūros sistemą. Kiti ekspertai kvestionavo netinkamai sudètus prioritetus, neadekvatų lèšu paskirstymą sistemos viduje, pvz., buvo pastebėta, jog ligonių kasos apmoka tik trečdalị ligonių konsultacijų, likusios turi būti teikiamos nemokamai; nors yra kuriamos prevencinès visuomenès psichikos sveikatos stiprinimo programos, tačiau nenumatoma pakankamai lèšų joms vykdyti. Ilgus metus vykdomojoje valdžioje dirbanti tyrimo dalyvė teigia, jog psichikos sveikatos problemų prevencijai iš visų Europos Sajungos valstybių Lietuva investuoja mažiausiai. Pašnekovès teigimu, Lietuvoje vienam gyventojui tenkanti suma kelis kartus skiriasi ne tik nuo turtingiausių, bet ir nuo naujujų Europos Sąungos šalių. Psichosocialinę negalią turinti pašnekovė ir tyrime dalyvavęs psichiatras kritikavo stacionarios globos sistema, kuri pažeidžia visas pagrindines savo klientų teises, tačiau jai atitenka didžiausi finansų srautai, skurdinant kitas - modernesnes, inovatyvias bendruomenines paslaugas. Stacionarios globos isstaigos yra viena ydingiausių psichikos sveikatos priežiūros sistemos dalių ne tik Lietuvoje, bet ir visame posovietiniame regione. Kartu jos sudaro vieną inertiškiausių sistemos segmentų, kaip teigè universitetui atstovaujantis ekspertas: Niekas, ne viena vyriausybe nebande šito klausimo spręsti.

Lietuvos psichikos sveikatos sistemoje dominuoja biomedicininis modelis - jo atžvilgiu daugiausia kritikos reiškè socialinės apsaugos sistemos ir akademinio sluoksnio atstovai, pastebėdami psichiatrijoje vykstanti piktnaudžiavimą medikamentiniu gydymu, - užuot nuodugniau 
ištyrus pacienta, eksperimentuojama vaistais. Atitinkamai nukreipiami ir finansavimo srautai, didžiausią lèšų dali skiriant vaistams, o ne psichosocialinès reabilitacijos paslaugoms. Kaip pastebejo ekspertai, tai ne tik mokslo žinių apie gydymą stygius, bet ir lobistinès farmacinių kompanijų veiklos išdava. Ju įtaka stipri, kadangi psichikos sveikatos politikai trūksta nuoseklumo, o kitų veikiančių jègų, pvz., psichiatrų asociacijos ir pacientų organizacijų vaidmuo yra niekinis, kaip teigé vienas ekspertų, psichiatras ir akademinio sluoksnio atstovas, apžvelgdamas visą potencialių ir realių i̇takos grupių spektrą ir poveiki psichikos sveikatos politikai. Dar viena neoficiali, tačiau reikšminga ir ittakinga lobistinè grupė yra įstaigu vadovai - psichiatrijos ligoninių direktoriai, kuriuos profesorius Dembinskas vadino kumščiu (ją identifikavo psichiatrijai atstovaujantis ekspertas), bei socialinės globos namų direktoriai (ivardyti socialinès apsaugos sistemos atstovès). Būdami suinteresuoti išlaikyti savo įtaka, didelių stacionarias gydymo ar globos paslaugas teikiančių istaigu vadovai bent jau iki šiol sẻkmingai priešinasi decentralizacijos ir deinstitucionalizacijos procesams, kurie, savo ruožtu, užkerta kelią bendruomeninių paslaugų plètrai.

Lobistiniai įstaigu vadovų interesai, nors ir netiesiogiai, randa netolerantiškos ir stigmatizuotos visuomenès palaikymą. Kaip pastebi ekspertai, Lietuvos visuomenė pasisako už psichosocialinę negalią turinčių asmenų izoliaciją ir priverstini gydyma, bijo jų tariamos agresijos ir polinkio nusikalsti. Aš esu išauklèta sovietmečiu, teigia tyrime dalyvavusi vykdomosios valdžios atstovè, ir prisipažista bijanti bei nemokanti bendrauti su psichosocialinę negalią turinčiais asmenimis. Tyrimo ekspertas, psichiatras, analogiškas tendencijas priskiria visam politiniam elitui: politikai neturi apskritai jokio supratimo apie psichikos sveikata dèl stigmos. Ši stigma trukdo psichikos sveikatos sistemos reformai: kaip teigia tas pats ekspertas, dominuojančios nuomonès neatitinkantys, palankūs politikų pasisakymai apie psichosocialinę negalią turinčių asmenų teises gali sukelti visuomeneje asociacijas apie tariamas paties politiko psichikos sveikatos problemas. Jo nuomone, politinès darbotvarkės viršūnejje psichikos sveikatos klausimai gali atsidurti tik tuomet, kai patys politikai viešai prisipažins apie savo psichiatrinę patirtị.

Dèl šių aplinkybių psichikos sveikatos srityje diegiamos inovacijos dažniausiai yra fragmentiškos, epizodinès, apsiriboja pilotiniais modeliais, arba opiems klausimams spręsti kuriamomis darbo grupėmis. 
Atkūrus nepriklausomybę Lietuva turèjo galimybę semtis pažangios patirties iš Vakarų, buvo sudaromos sąlygos susipažinti su užsienio šalių psichikos sveikatos priežiūros sistemomis, tobulinti savo kvalifikacija dalyvauti gerosios patirties sklaidos renginiuose, buvo remiama istaigu modernizacija ir nauju paslaugų diegimas. Tačiau, kaip pastebi ekspertai, entuziastingų asmenų arba organizacijų pradètos inovacijos sunkiai issitvirtino, netapo bendra praktika. Modernios paslaugos, kurias, pritraukdamos tarptautines lèšas, mègina diegti nevyriausybinès organizacijos, Lietuvoje negauna finansavimo arba net mėginamos išstumti iš psichikos sveikatos priežiūros sistemos. Ekspertai vardija Lietuvoje bandantị įsitvirtinti Paciento patikètinio modelị, Psichosocialinès reabilitacijos centra, Savarankiško gyvenimo namus ir net Psichikos sveikatos strategija, kurią lydèję priemonių planai apsiribojo kukliu finansavimu ir atspindejo primityvų visuomenès psichikos sveikatos poreikių suvokimą.

Psichikos sveikatos strategija laikoma kertiniu dokumentu Lietuvos psichikos sveikatos priežiūros sistemos reformai, siekiant veiksmingai, racionaliai, vadovaujantis šiuolaikinėmis mokslo žiniomis ir vertybėmis, stiprinti visuomenės psichikos sveikata, teikti visapusišką pagalbą psichikos ir elgesio sutrikimų turintiems asmenims bei jų šeimoms (Pūras ir kt., 2013), tačiau, kaip teigia šie autoriai, igyvendinimo lygyje stebima stagnacija, kai valstybės psichikos sveikatos politika vykdoma remiantis ne šiuolaikiniais principais, o proteguojant iprastus, seniai susiformavusius investavimo į sistemą būdus bei atsiliepiant į visuomenèje stipriai išreikštas stigmos, socialinès atskirties ir netolerancijos nuostatas. Komentuodamas Lietuvos sėkmę priimant Psichikos sveikatos strategiją ir nesėkmę nededant pastangų tinkamai ja vadovautis, tyrime dalyvavęs buvęs Vyriausybės narys politinius rinkimų ciklus ir politinių figūrų kaitą identifikuoja kaip neigiamą poveikį turinčią aplinkybę formuojant ir igyvendinant psichikos sveikatos politiką: keičiasi turbūt vyriausybès, keičiasi ministrai, keičiasi valdžia, labai lengvai užgesina ir šitos srities profesionalu entuziazma, kurị paskui būna labai labai sunku vèl iš naujo... ižziebti.

Aktyviausi sistemos kritikai ir nauju paslaugų teikimo modelių iniciatoriai yra nevyriausybinės organizacijos, tačiau visuomeninio sektoriaus atstovai, kaip pastebi tyrimo ekspertai, psichikos sveikatos srityje nèra itakingi politiniai veikejjai, jų veikla vertinama kaip sisteminio poveikio stokojančios pavienės iniciatyvos. Vienintelis tyrimo dalyvis, pabrèžęs 
svarbų NVO vaidmeni psichikos sveikatos politikoje, savo teiginį iliustravo tik kukliais pavyzdžiais apie jų organizuojamas konferencijas, seminarus ir tyrimus. Tačiau nevyriausybinės organizacijos paprastai aktyviai pritraukia užsienio ekspertus ir fondus, skatina prisijungti prie tarptautinių dokumentų (ekspertai minejjo Neigaliųjų teisių konvenciją). Dauguma ekspertų išskyrė tarptautini kontekstą kaip vieną reikšmingiausių veiksnių, dariusių itaką psichikos sveikatos politikos formavimui. Tai ir Europos Sajunga, ir Jungtinès Tautos, tarptautinès bendruomenès poveikis ir spaudimas, užsienio specialistų patirtis, atsivèrusi atkūrus nepriklausomybę ir deklaravus demokratijos siekius. Ypač Europos Sajunga ekspertų buvo pabrèžiama kaip vienas iš išorinių veiksnių, orientuotų i teigiamus pokyčius psichikos sveikatos priežiūros sistemoje, tiek dèl papildomų finansinių išteklių, kuriuos teikia Struktūriniai fondai, tiek dèl pažangių teisès aktų, skatinančių pagarbą žmogaus teisèms bei nuolatinès situacijos stebėsenos ir ES viduje vykdomo tarptautinio palyginimo. Vis dèlto, ekspertų nuomone, Europos Sajungos skirtos lèšos ir diegiamos inovacijos neatnešė esminių sisteminių pokyčių, o buvo internalizuotos îprastomis institucinemis praktikomis - pavyzdžiui, deklaratyvaus pobūdžio teiginys „psichosocialinę negalią turinčių asmenų integracija ị visuomenę "įrašytas į beveik kiekvienų socialinès globos ịstaigu įstatus, o Struktūrinių fondų lèšos buvo skiriamos tų pačių îstaigu rekonstrukcijai, o ne bendruomeninių paslaugu plètrai.

Savivaldybių lygyje veikiantys psichikos sveikatos centrai, laikomi valstybės vykdomos psichikos sveikatos priežiūros reformos pagrindu, nusipelnè ypatingo ekspertų dèmesio ir prieštaringų vertinimų. Nors tikimasi, kad pirminio lygio grandies paslaugų teikejjai turi mokèti diagnozuoti ir suteikti pagalbą daugumos nekomplikuotų ligų ir sutrikimų atvejais, psichikos sveikatos apsaugos srityje daroma išimtis ir pirminiame sveikatos priežiūros lygyje pagalbą teikia specializuoti psichikos sveikatos centrai. Teigiamai juos vertino tik du tyrimo dalyviai, vienas ju pats šiuo metu vadovauja vienam iš sostinès psichikos sveikatos centrų. Pastebėtina, kad teigiamai apie šią psichikos sveikatos priežiūros grandi atsiliepę ekspertai apsiribojo konstatavimu: prie sèkmiu galbūt priskirčiau psichikos sveikatos centru atsiradima, neargumentuodami šiu savo teiginių ir nepagrișdami pavyzdžiais ar statistine informacija. Tuo tarpu oponuojantys tyrimo dalyviai negailejjo kritikos, skaičių ir argumentų. Pasak jų, 
psichikos sveikatos centrams nustatyti aiškūs veiklos prioritetai, o didelès darbų apimtys (pacientu prasme, jie jau yra isotinti ir persotinti; konsultaciju ten yra per du milijonai, - kaip teigè tyrime dalyvavę psichiatrai) ir nediferencijuotas pacientu srautas (jokiu filtru) lemia, kad nei psichikos sveikatos sutrikimu prevencija, nei pagalba lengvų, vidutinių ar sunkių sutrikimų turintiems asmenims negali būti vykdoma sẻkmingai. Ši infrastruktūra buvo kuriama tam, kad, be kitų svarbių tikslų, stabdytų sergančiujų sunkesnèmis psichikos ligomis patekimą i socialinės globos namus, tačiau psichikos sveikatos centrams nenurodyta siekti šio tikslo. Pažymètina, kad šie centrai ir neturi tokios galimybès, atsižvelgiant ị labai menką juose įdarbintų socialinių darbuotojų skaičių.

Savivaldybių psichikos sveikatos centrų finansavimas, žmogiškuju ištekliu politika ir veiklos sistema pirminį lygi atstovaujančiai bendrosios pagalbos gydytojų institucijai trukdo realiai i̇sitraukti i psichikos sveikatos problemų sprendima, taip pat užkerta kelią plètoti efektyvias paslaugas sunkių sutrikimų atveju: aš net nesu tikras, ar tai konsultacijos abejojo vienas tyrimo ekspertu, kritiškai atsiliepdamas apie psichikos sveikatos centrų teikiamas paslaugas komplikuotais atvejais. Psichikos sveikatos centrai dèl itin medikalizuotos žmogiškuju išteklių politikos dažnai apsiriboja medikamentiniu gydymu, hospitalizacijomis, apgyvendinimo socialinès globos namuose organizavimu bei i̇vairių pažymų išdavimu gyventojams ir neveikia kaip kertinė bendruomeninių paslaugų teikimo grandis.

Analogiškai ekspertų nuomonès išsiskyrè ir vertinant dienos stacionarus. Lietuvoje dienos stacionarai buvo kuriami prie savivaldybėse egzistuojančios psichikos sveikatos centrų infrastruktūros, siekiant plètoti psichikos sveikatos paslaugu prieinamumą. 27 dienos stacionarų steigimui buvo panaudota Europos Sajungos struktūrinių fondų parama. Atliekant tyrima, pastebèta panaši tendencija kaip ir vertinant psichikos sveikatos centrus: palankiai atsiliepiantys tyrimo dalyviai lakoniškai konstatavo savo teigiamą nuomonę apie jų veiklą, skeptiškai vertinantys šią psichikos sveikatos priežiūros sistemos grandị negailëjo kritikos ir neigiamų pavyzdžių apie šių įstaigų nesėkmes.

Vykdomosios valdžios atstovė dienos stacionarų steigimą ir veiklą vadina psichikos sveikatos politikos sẻkme, kaip užsienio šalyse pasiteisinusią ir Lietuvoje prigyjančią inovaciją. Psichiatrijos ligoninèje 
dirbanti pašnekovė dienos stacionarų atžvilgiu kur kas kritiškesnè, ji dienos stacionarus priskiria prie psichikos sveikatos priežiūros sistemos nesėkmių. Psichiatrès nuomone, Lietuvoje pradedanti funkcionuoti dienos stacionarų sistema apsiriboja paviršutinišku ir primityviu pacientų užimtumo organizavimu (jokių reabilitacijos programu, jokiu užsièmimu, jokiu mokymu, nieko nèra) ir taip kompromituoja veiksminga, pažangią ir Vakarų Europoje gerų rezultatų pasiekiančią psichikos sveikatos priežiūros paslaugų teikimo formą: aš savo rezidentams, dar kai mokiau, sakiau: eikit pažiūrèt, kaip neturi būt.

Stokojant aiškios vizijos bei politinės valios, gailintis naikinti materialųji ir pasąmonẻje glūdintị sovietmečio psichiatrijos paveldą ir baiminantis lobistų kumščio psichikos sveikatos sistemos reforma veikiausiai neivyks. Tyrime dalyvavęs akademinio sluoksnio atstovas, turintis darbo Vyriausybejje patirties, nuoseklų planavimą identifikuoja kaip būdą priimti ir igyvendinti veiksmingus psichikos sveikatos politikos sprendimus. Jo teigimu, reforma turi remtis įrodymais grindžiamomis prevencinėmis, intervencinėmis ir profilaktinėmis programomis, nepaisant to, kad: tokia sistema yra didelis iššūkis sukurti, reiktu ìvardinti tiesiai šviesiai, kad tai brangiai kainuoja, kad tai nèra paskaitu skaitymas ar kažkoks tai diletantiškas požiūris.

Atsitiktinių savieigai paliktų inovacijų rinkinys ir tvirtai ikabintas sovietinio paveldo inkaras - toks Lietuvos psichikos sveikatos sistemos dualizmas išryškėjo atlikus ekspertų tyrimą. Ji galima vertinti kaip dvi konkuruojančias ideologines tradicijas, tikintis, jog neveiksminga, neracionaliai naudojančią išteklius ir šiuolaikinių psichikos sveikatos politikos principų neatitinkančią psichikos sveikatos priežiūros sistemą pakeis modernių paslaugu plètra. Kol tai neivvyko, stebima priešinga tendencija, kai esama sistema stiprèja absorbuodama inovacijas, plèsdama esamas struktūras ir viešajame diskurse pristatydama jas kaip sėkmingas praktikas. Tarptautiniame lygmenyje tokios taktikos naudojimas leidžia užbėgti už akiu i̇takingų organizaciju priekaištams, kokie buvo išsakyti Rytų Europos vyriausybėms 1999 m. vykusiame jungtiniame Pasaulio sveikatos organizacijos ir Europos Komisijos susitikime, kad aktyviausiai psichikos sveikatos srities reformą palaiko NVO sektorius, o vyriausybės vaidmuo dažniausiai statiškas arba negatyvus (Knapp, McDaid, Mossialos, Thornicroft, 2007, p. 25). 


\section{IŠVADOS}

Visuomenès psichikos sveikatos rodikliai jautriai reaguoja i jos narių patiriamus socialinius, politinius ar ekonominius iššūkius. Lietuvos visuomenè, kaip ir kitų posovietinių valstybių visuomenės, buvo traumuojama ir komunistinio režimo, ir, jam žlugus, pasikeitusios politinès santvarkos, sumažèjusio žmonių socialinio ir ekonominio saugumo. Senosios santvarkos principais veikianti psichikos sveikatos priežiūros sistema nesugeba adekvačiai atsiliepti i i isisenejjusias ir kylančias naujas problemas, tačiau, nepaisant akivaizdžių nesėkmių, jos reforma neatsiduria politinės darbotvarkès viršūnèje. Toki politinės valios trūkumą lemia visuomenėje ir tarp politikų egzistuojanti psichosocialinės negalios stigma, psichikos sveikatos priežiūros sistemos inertiškumas, priklausomybè nuo fizinio, institucinio ir dvasinio paveldo bei dominuojančios interesų grupės.

Atkūrus nepriklausomybę, Lietuva turëjo vidines ir išorines prielaidas esminiams psichikos sveikatos priežiūros sistemos pokyčiams. Buvo anksti diagnozuotos sisteminės problemos, bendradarbiaujant su užsienio partneriais perimama patirtis ir gaunama tarptautine parama, aktyviai veike psichikos sveikatos srities nevyriausybinès organizacijos ir tarptautinio lygio ekspertai, buvo perimamos Europos Sąjungos vertybės, derinama teisinė bazè, gaunama Struktūrinių fondų parama, tačiau politinių sprendimų prièmimo ir igyvendinimo lygmenyje vyravo inertiniai, priešiški pokyčiams mechanizmai.

Nevyriausybinių organizacijų iniciatyva diegiamos inovatyvios paslaugos yra epizodinès, stokoja institucinio bei finansinio tęstinumo. Savo pažangumu jos išsišoka iš bendro stagnacijos konteksto, kvestionuoja biomedicinini paslaugų teikimo modeli ir kelia grèsmę psichikos sveikatos priežiūros sistemos homeostazei. Todèl ilgainiui šios paslaugos „numarinamos“ kaip nepasiteisinusios ir grižtama prie tradicinių paslaugų teikimo būdų.

Politinių sprendimų keliu atsirandančios naujos paslaugos ar tarnybos dažniausiai yra tarptautinių organizacijų imperatyvas Lietuvai. Nepaisant saistančių tarptautinių sutarčių, diegiant šias naujoves dažniausiai apsiribojama fasadiniais pokyčiais, jos integruojamos i iprastas sistemines praktikas ir nesuardo iki tol egzistavusios institucinès sąrangos. Tokiais atvejais pasiekiama dviguba pergalè: inovacijas galima pristatyti 
kaip modernius tarptautinius standartus atitinkančius pasiekimus, tačiau jie nesutrikdo sistemos stabilumo ir leidžia išsaugoti egzistuojantị psichikos sveikatos priežiūros modelì.

Psichikos sveikatos priežiūros sistemoje galima išskirti dviejų tipų elitą: vienam atstovauja ilgus metus sistemoje dirbantys asmenys (politikai, valdininkai, istaigu vadovai), kitam - sistemos reformatoriai (NVO atstovai, mokslininkai, psichosocialinę negalią turintys asmenys). Sistemos elitas ir reformatoriu elitas vadovaujasi skirtingais interesais, jie skirtingai suvokia Lietuvos psichikos sveikatos priežiūros sistemos būklę, jos reformos eigą ir ateities viziją. Sistemos elito atstovai dominuoja priimant ir igyvendinant politinius sprendimus, reformatorių elito dalyvavimas labai epizodinis arba išvis nepasitelkiamas. Tais epizodiniais atvejais, kai (dažniausiai esant tarptautiniam spaudimui) reformatoriai itraukiami i strateginio dokumento kūrima, igyvendinimo, finansavimo skyrimo, realaus politinio poveikio lygmenyje jis neužpildomas realiu turiniu.

\section{LITERATÜRA}

1. Bogner, A., Littig, B., Menz, W. (2009). Interviewing experts. Research methods series. Basingstoke England, New York: Palgrave Macmillan.

2. Knapp, M., McDaid, D., Mossialos, E., Thornicroft, G. (ed.) (2007). Mental Health Policy and Practice across Europe. Buckingham: Open University Press.

3. Liebold, R., Trinczek, R. (2002) Experteninterview. Kühl, S., Strodtholz, P. (Hrsg.). Methoden der Organisationsforschung. Ein Handbuch. Reinbek: RoRoRo.

4. Meuser, M., Nagel, U. (2005). ExpertInneninterviews - vielfach erprobt, wenig bedacht. In: Bogner, A., Littig, B., Menz, W. (Hrsg.). Das Experteninterview Theorie, Methode, Anwendung (2-as leidimas). Wiesbaden: VS Verlag für Sozialwissenschaften.

5. Pfadenhauer, M. (2005). Das Experteninterview - ein Gespräch zwischen Experte und Quasi-Experte. Bogner, A., Littig, B., Menz, W. (Hrsg.). Das Experteninterview - Theorie, Methode, Anwendung (2-as leidimas). Wiesbaden: VS Verlag für Sozialwissenschaften.

6. Pūras, D., Šumskienė, E., Veniūtè, M., Murauskienė, L., Šumskas, G., Diržienė, J., Juodkaite, D., Šliužaitė, D. (2013) Mokslo studija „Iššūkiai igyvendinant Lietuvos psichikos sveikatos politiką“. [žiūrèta 2014-05-10]. Prieiga per internetą: http://naujienos.vu.lt/wp-content/uploads/2014/03/ issukiai-igyvendinant-Lietuvos-psichikos-sveikatos-politika.pdf 


\section{SUMMARY}

\section{CHECK OUT THE WAY IT SHOULDN'T BE MANAGED: MENTAL HEALTH POLICY DEVELOPMENT AND OUTCOMES}

The article presents results of the qualitative experts' research which was conducted in 2012-2013 within the frame of a project "Challenges of Implementation of Lithuanian Mental Health Policy". The article analyzes development of the Lithuanian mental health care system from the perspectives of its' supporters and critics. Special attention is drawn on the relationship between practices inherited from the Soviet time and modern innovations which are slowly gaining momentum. Authors of the article come to the conclusion that the mental health care system is based on out-dated principles and that it is unable to adequately respond to chronic and newly emerging problems; despite of these obvious failures in the implementation level mental health reform never appears on the political agenda as a serious issue of a strategic level to be discussed.

Non-governmental organizations pilot and introduce new mental health services which are distinguished by their innovative nature, and incompatibility with the general stagnating context within the mental health care system. The inert system perceives these innovations as threats to its' homeostasis and reacts in the traditional direction towards its restoration: a) either new services are financially and institutionally suppressed as unjustified and the system returns to its equilibrium; or (b) new services become integrated into customary systemic practices thus strengthening the former institutional design.

Researchers also distinguish between the two types of stakeholders within the mental health care system, who differ significantly in understanding of the status quo and the future of the system. One group is represented by long-term representatives of the system (politicians, officials, directors of institutions), the second group is represented by reformers of the system (members of NGOs, academics, relatives of service users). The first group dominates in the process decision making and implementation whereas role of the second group in the policy making process remains very small. 